\title{
Role of I-TAC-binding receptors CXCR3 and CXCR7 in proliferation, activation of intracellular signaling pathways and migration of various tumor cell lines
}

\author{
Katarzyna Miekus, Danuta Jarocha, Elzbieta Trzyna, Marcin Majka
}

Department of Transplantation, Polish-American Institute of Pediatrics, Jagiellonian University School of Medicine, Cracow, Poland

\begin{abstract}
Chemokines and its receptors stimulate tumor growth, migration and invasion. In this study we evaluated the expression and function of CXCR3 and CXCR7 receptors in cervical carcinoma, rhabdomyosarcoma and glioblastoma cell lines. We found that both receptors were expressed at different degree by tumor cells. CXCR7 was expressed at both mRNA and protein level by all tumor cell lines. The expression of CXCR7 differed between rhabdomyosarcoma subtypes. The receptor was highly expressed in alveolar rhabdomyosarcoma and the expression was low in embryonal rhabdomyosarcoma. The expression of CXCR3 was low in majority of the tumor cell lines. Upon I-TAC stimulation AKT and MAPK kinases were activated. However, the activation of growth promoting pathways did not increased the proliferation rate of tumor cells. Since chemokines stimulate the migration of various cell types the ability of I-TAC to stimulate migration of tumor cells were studied. We did not observe the migration of tumor cells toward I-TAC gradient alone. However, at the low dose, I-TAC sensitized tumor cells toward SDF- $1 \beta$ gradient and synergized with SDF-1 $\beta$ in activation of intracellular pathways. Our data suggest an important role of I-TAC and its receptors in biology of solid tumors and we postulate that I-TAC-binding receptors might be used as the potential targets for antitumor therapy.
\end{abstract}

Key words: CXCR7, CXCR3, I-TAC, SDF-1, tumor, migration, phosphorylation

\section{Introduction}

Tumor growth is a very complex process including mutations of suppressor genes and oncogenes, uncontrolled proliferation and resistance to apoptosis, migration and invasion of surrounding tissues and distant organs [1]. Several surface receptors including growth factor, cytokine and chemokine receptors and their ligands play a role in facilitating tumor growth [1].

The major function of chemokines and chemokine receptors is to facilitate the migration of various cells types particularly of hematopoietic origin [2]. They are responsible for migration of immunocompetent cells to the sites of inflammation and pathogen invasion [2]. In some cases they can also provide the entrance for pathogens into our body [3].

Correspondence: K. Miekus, M. Majka, Dept. of

Transplantation, Polish-American Institute of Pediatrics, Jagiellonian University, Wielicka Str.265, 30-663, Cracow, Poland; tel.: (+4812) 6591593, fax.: (+4812) 6591594, e-mail:kmiekus@gmail.com,mmajka@cm-uj.krakow.pl
Chemokines and chemokine receptors are very important in cancerogenesis and metastasis. Recent studies have shown that activation of chemokine receptors by their ligands can stimulate tumor proliferation, resistance to apoptosis and tumor cells movement [4]. One of the most important and the best studied receptor involved in these processes is CXCR4, a member of the family of G-protein-coupled sevenspan transmembrane receptors. CXCR4 plays a role in metastasis of breast cancer [5], lung cancer [6], neuroblastoma [7] and rhabdomyosarcoma [8]. Its CXCR4 ligand, stromal derived factor 1 (SDF-1), is constitutively expressed in various tissues and it is responsible for directing tumor cells invasion and metastasis [4]. Its expression can be enhanced by chemo- and radiotherapy and lead to even faster spreading of tumor cells [4]. CXCR4 has long been considered as the unique receptor for SDF-1 and the only mediator of SDF-1-induced biological effects [9]. However, recently, SDF-1 was shown to bind with a high affinity to the orphan receptor $\mathrm{RDC} 1$, later 
renamed CXCR7 [10,11]. The affinity of SDF-1 to CXCR7 is approximately ten fold higher than the affinity of SDF-1 to CXCR4 [12].

CXCR7 is expressed on tumor cell lines $[13,14]$, activated endothelial cells [14], and early fetal liver cells [11]. Despite its high affinity to SDF-1, the role of CXCR7 in SDF-1-dependent cell motility, chemotaxis and calcium flux has been a subject of debate. Recent studies confirmed a critical role of CXCR7 in tumor vascular formation, angiogenesis and cell proliferation and survival [12]. Recently, it has been shown that CXCR7 forms functional heterodimers with CXCR4 and influences SDF-1 mediated CXCR4 signaling [15]. Besides binding to SDF-1, CXCR7 is also a receptor for inducible $\mathrm{T}$ cell alpha chemoattractant (I-TAC) [11]. I-TAC also binds to CXCR3 chemokine receptor. CXCR3 is preferentially expressed on the surface of Th1 T cells. CXCR3 has been localized to infiltrating effector T cells of the Th1 type in a wide variety of human inflammatory diseases [16]. Through CXCR3, I-TAC directs migration of Th1 lymphocytes [16] and it has been shown to influence epidermal maturation during wound healing [17].

Cervical carcinoma (CC) is one of the major causes of mortality and morbidity among women suffering from cancer in low and medium income countries including Poland [18]. It is mostly due to the late diagnosis at the advanced stage of the disease, often with distant metastasis [18]. Metastasis are primarily to lungs, liver, bones and bone marrow. Rhabdomyosarcoma (RMS), the most common pediatric soft tissue sarcoma can be divided into two major subtypes embryonal RMS (ERMS) and alveolar RMS (ARMS)) based on histopathological and molecular features [19]. ARMS expresses fusion proteins PAX3-FKHR and PAX7-FKHR $[20,21]$ and the presence of these fusion genes has been shown to correlate with the high risk of relapse, metastasis (often to bone marrow) and overall worse prognosis [22-24]. Glioblastoma multiforme (GMB) is a rare tumor with incidence of 2 cases per 100000 people per year [25]. However, among tumors developed in nervous system it accounts $25 \%$ of all malignant tumors [26]. The survival rate of GMB patients is very low, approximately $30 \%$ at one year and less than $3 \%$ at five years [26].

Since the role of CXCR7 and CXCR3 receptors during carcinogenesis and metastasis is still largely unknown, the purpose of this study was to evaluate the presence and function of these receptors and their ligand, I-TAC, in cervical carcinoma, rhabdomyosarcoma and glioblastoma multiforme models.

\section{Materials and methods}

Cell lines. Cervical carcinoma cell lines (CC): HTB-34, HTB-35 and HeLa, were maintained in MEM supplemented with $10 \%$ FBS Rhabdomyosarcoma cell lines (RMS): RH30, RH18, RH28,
CW9019, SMS-CTR, RD were kindly gifted by M.Z. Ratajczak (University of Louisville, KY, USA) and maintained in DMEM supplemented with 10\% FBS. Glioblastoma cell lines (GMB): LN18, LN229, T98G were generously provided by K. Reiss (Temple University, Philadelphia, USA) and were maintained in DMEM supplemented with $10 \%$ FBS. All the cells were cultured at $37^{\circ} \mathrm{C}$, $5 \% \mathrm{CO}_{2}, 95 \%$ humidity. They were split twice a week with medium change.

Flow cytometry. The presence of CXCR7 and CXCR3 receptors on the surface of target cells were demonstrated by staining with rabbit anti-CXCR7 primary antibody (Abcam, Cambridge, MA, USA), anti-rabbit-FITC secondary antibody (Becton Dickinson, Franklin Lakes, NJ, USA) and mouse anti-CXCR3-APC (Becton Dickinson, Franklin Lakes, NJ, USA) and analyzed by FACS. Briefly, $1 \times 10^{5}$ cells were suspended in $100 \mu$ of staining buffer (PBS, 2\% FBS) and rabbit or mouse Ab was added. Next, cells were incubated in the dark for $30 \mathrm{~min}$. at $4^{\circ} \mathrm{C}$. The stained cells were washed, and in the case of CXCR7 the secondary antibody was added and the staining procedure was repeated. After staining, cells were collected using FACSCanto cytometer (Becton Dickinson, San Jose, CA, USA) and analyzed with FACS Diva software (Becton Dickinson, San Jose, CA, USA).

RNA extraction and reverse transcription. Total RNA was extracted using RNeasy Mini Kit (Qiagen, Hilden, Germany) followed by DNAse treatment (Promega, Madison, WI, USA). The reverse polymerase transcription was performed using MMLV reverse transcriptase (Invitrogen, Carlsbad, CA, USA) according to the manufacturer's protocol.

Quantitative real time PCR analysis. The expression of CXCR7 was determined by quantitative real time PCR analysis on ABI PRISM 7300 Sequence Detection System (Applied Biosystems, Foster City, CA) using a commercially available PCR Master Mix. The primers/probe set for CXCR7 (Hs00604567 m1) was used. The mRNA expression level for all samples was normalized to the housekeeping gene GAPDH (Hs99999905 m1). All primers/probes sets were from Applied Biosystems (Foster City, CA, USA).

Western blot. Western blots were done on extracts prepared from cells stimulated with I-TAC, SDF-1 $\beta$ or both ligands together (ITAC $10 \mathrm{ng} / \mathrm{ml}$ and SDF-1 $10 \mathrm{ng} / \mathrm{ml}$ ) as described previously [27]. Briefly, the cells were lysed (for $10 \mathrm{~min}$ ) on ice in M-Per lysing buffer (Thermo Scientific, Rockford, IL, USA) containing protease and phosphatase inhibitors (Sigma, St. Luis, MO, USA). The proteins were separated on a $10 \%$ SDS-PAGE gel and transferred to a PVDF membrane. The phosphorylation of intracellular pathway proteins was examined after stimulation with ITAC or SDF-1 for 5 min. The phosphorylation of 44/42 MAPK and AKT proteins were detected by phospho-specific mouse p42/44 MAPK and rabbit AKT antibody (Cell Signaling, Danvers, MA, USA) and HRP-conjugated goat anti-rabbit and anti-mouse secondary antibody (Santa Cruz Biotech, CA, USA). The membranes were developed with an enhanced chemiluminescence (ECL) reagent (Thermo Scientific, Rockford, IL, USA), dried, and subsequently exposed to the HyperFilm (Amersham Life Sciences, Buckinghamshire, UK). An equal loading in the lanes was evaluated by probing with an anti GAPDH antibody (Cell Signaling, Danvers, MA, USA). For densitometry analysis blots were scanned and analyzed with Kodak Molecular Imaging Software, Version 4.5

Cell Proliferation/Survival Assay. The cell proliferation/survival assay was performed using CellTiter 96 Aqueous One Solution Kit accordingly to the manufacturer's recommendations (Promega, Madison, WI, USA). Cells (CC: HTB-35, RMS: RH30 and GMB: LN229), were seeded in 96 -well plates at $2 \times 10^{3} /$ well in $200 \mu \mathrm{l}$ of 
A
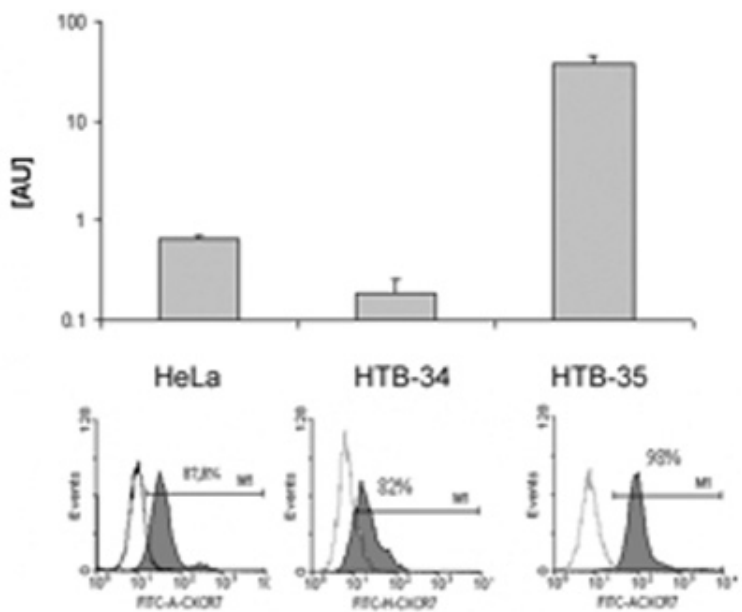

\section{B}

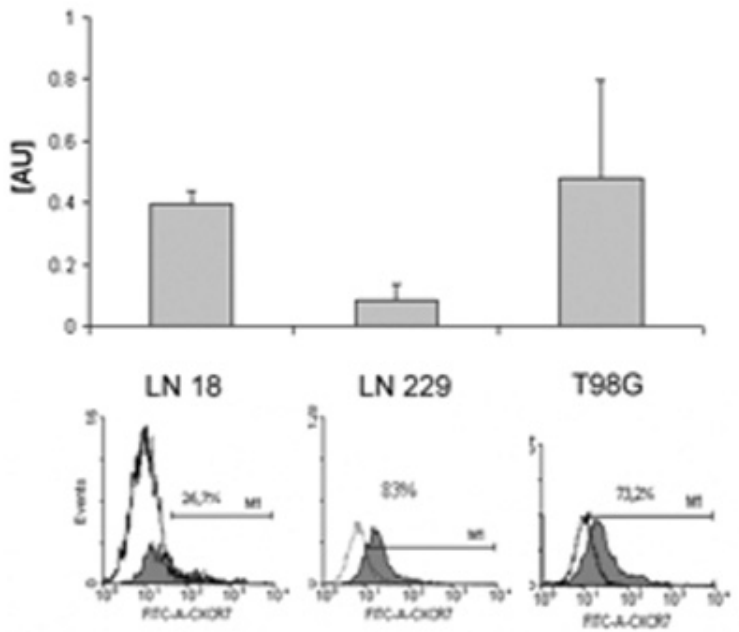

C
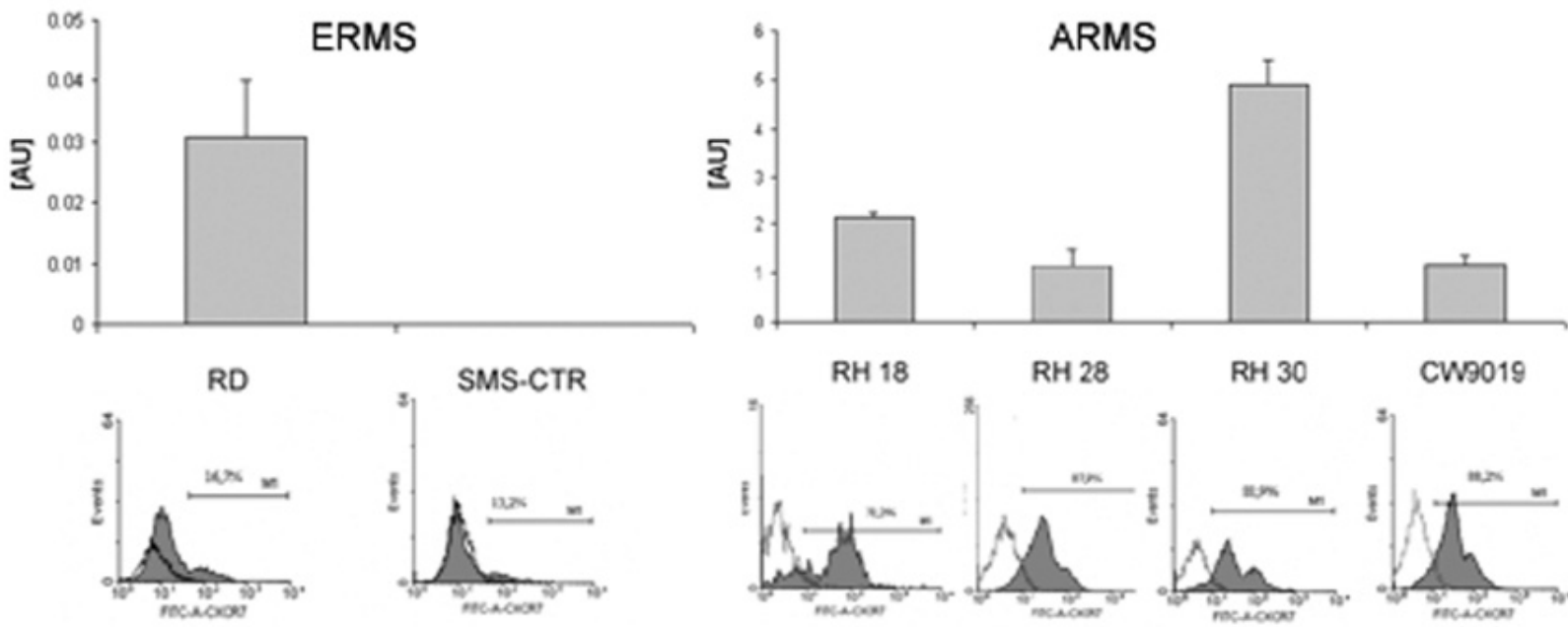

Fig. 1. Expression of CXCR7 by various tumors cell lines. Using real time RT-PCR (upper panels) and cytofluorymetric analysis (lower panels) expression of CXCR7 receptor has been studied in A - cervical carcinoma cell lines, B - glioblastoma and C - rhabdomyosarcoma. For mRNA analysis experiments were repeated twice and average data with SD are shown. For FACS analysis experiments were repeated also twice and representative staining is shown; [AU] arbitraty units.

DMEM medium containing 0.5\% BSA (control), 10\% FBS (positive control), $0.5 \%$ BSA and I-TAC (1 or $10 \mathrm{ng} / \mathrm{ml}$ ). After 24,48 , 72 and 96 hours, $20 \mu 1$ of CellTiter 96 Aqueous One Solution reagent were added to each well and plates were incubated for 3 hours. Subsequently, plates were read at $490 \mathrm{~nm}$ using the $\mathrm{EL} \times 800$ Universal Microplate Reader (Bio-tek Instruments, Highland Park, USA) and analyzed with KC4 v3.0 with PowerReports software. Each experiment was repeated three times and each concentration was in triplicates.

Chemotaxis assay. The directional movement of cells toward ITAC (R\&D System, Minneapolis, MN, USA) and SDF-1 $\beta$ (PeproTech, Rocky Hill, NJ, USA) gradient was evaluated using modified Boyden's chamber with 8 - $\mu \mathrm{m}$ pore polycarbonate membrane inserts (Costar Transwell; Costar-Corning, Lowell, MA, USA). Cells detached with $0.25 \%$ trypsin were seeded into the upper chamber of an insert at the density of $2.5 \times 10^{4}$ in $100 \mu 1$. The lower chamber was filled with pre-warmed medium containing ITAC $(1,10,100 \mathrm{ng} / \mathrm{ml})$ and SDF-1 $\beta(10 \mathrm{ng} / \mathrm{ml})$ or both ligands together (I-TAC $10 \mathrm{ng} / \mathrm{ml}$ and SDF-1 $\beta 10 \mathrm{ng} / \mathrm{ml}$ ). $0.5 \%$ BSA DMEM medium was used as a negative control. After 24 hours, inserts were removed from the transwells and the cells were fixed with methanol. The cells that did not migrate were scraped off with cotton wool from the upper membrane and the cells that had transmigrated to the lower side of the membrane were stained with Wright solution and counted under high power field (HPF) with inverted microscope. Five fields were counted each time and the mean number of cells per HPF was calculated.

\section{Results}

The expression of $C X C R 7$ by rhabdomyosarcoma, cervical carcinoma and glioblastoma cells

The expression of CXCR7 in CC, GMB and RMS cell lines was analyzed using real-time RT-PCR and flow cytometry. All CC cell lines expressed CXCR7 at 
A
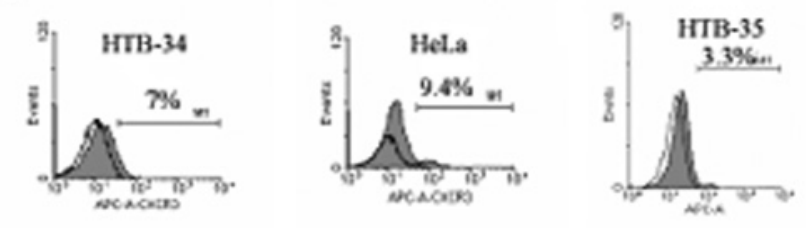

B
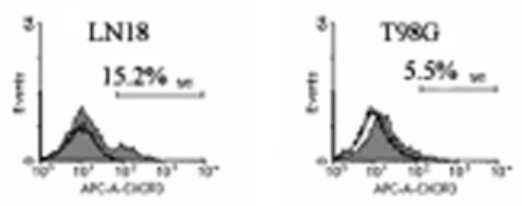

C
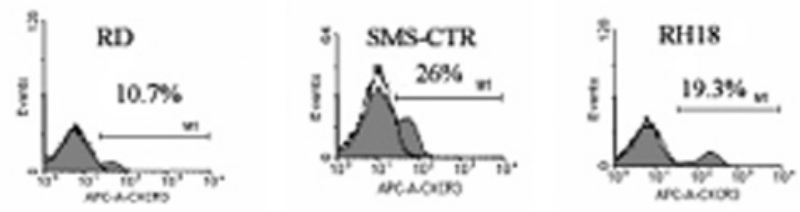
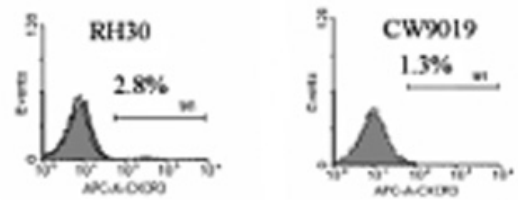

Fig. 2. Expression of CXCR3 by various tumors cell lines. Using cytofluorymetric analysis expression of CXCR3 receptor has been studied in A - cervical carcinoma cell lines, B - glioblastoma and C - rhabdomyosarcoma. Experiments were repeated twice and representative staining is shown.

mRNA level (Fig. 1A-upper panel). The surface expression of CXCR7 by CC cell lines was very high (HeLa - 87\%, HTB-34 - 82\%, HTB35 - 98\%) (Fig. $1 \mathrm{~A}$ - lower panel). GMB cell lines also expressed mRNA for the receptor (Fig. 1B-upper panel). However, surface expression varied from low for LN18 (25\%) to high T98G (72\%) and LN229 (83\%) (Fig. 1B-lower panel). We also looked for the expression of mRNA and proteins in RMS cell lines. In the case of embryonal subtype mRNA was detected in one cell line (RD) (Fig. 1C-upper panel) and the surface staining revealed very low expression of CXCR7. At the same time mRNA for CXCR7 was detected in all four alveolar cell lines and the surface expression was high (RH18 $78.2 \%$, RH28 - 87.9\%, RH30 - 88.9\%, CW9019 88.2\%) (Fig. 1C-lower panel).

\section{The expression of CXCR3 by rhabdomyosarco- ma, cervical carcinoma and glioblastoma cells}

Next, we checked the expression of CXCR3, the second I-TAC receptor. $\mathrm{CC}$ cell lines had low expression of CXCR3: HeLa - 10\%, HTB-34 - 7\% and HTB-35 - 3\% (Fig. 2A). GMB cell lines also expressed CXCR3 receptor (T98G - 6\%, LN18 - 15\%) (Fig. 2B). RMS cell lines expressed CXCR3 at the low level with higher expression seen for ERMS cell lines (Fig. $2 \mathrm{C})$.

\section{The activation of intracellular pathways by I-TAC}

We tested the ability of CXCR7 and CXCR3 ligand, ITAC, to activate various intracellular pathways. Cell lines were starved for 24 hours and subsequently stimulated with $10 \mathrm{ng} / \mathrm{ml}$ of I-TAC. CC cell lines had different pattern of AKT and MAPK phosphorylation. In $\mathrm{CC}$ cell line, HTB-35, I-TAC caused activation of
MAPK only after 10 min of stimulation with no sign of AKT activation. However in Hela cell line I-TAC stimulated phosphorylation of AKT and MAPK. In the case of AKT kinase we observed strong phosphorylation after 2 minutes, with no sign after 5 minutes. Again, after 10 minutes of stimulation strong phosphorylation, lasting until 30 minutes with visible increase, was observed. A pattern of phosphorylation was different for MAPK kinase with the strongest phosphorylation observed after 2 minutes and gradually diminishing after 10 minutes of stimulation (Fig. $3 \mathrm{~A}$ ). In the case of GMB and RMS cell lines (LN18 and RH30, respectively) maximum AKT kinase activation was observed 2 minutes after stimulation and gradually decreased (Fig. 3A). The effect of I-TAC on tumor cells proliferation was also measured. Cells were seeded in medium containing $0.5 \% \mathrm{BSA}$ and two concentrations of I-TAC $1 \mathrm{ng} / \mathrm{ml}$ and $10 \mathrm{ng} / \mathrm{ml}$. Medium containing $10 \%$ FBS was used as a positive control. We did noticed any changes in proliferation rate regardless of I-TAC concentration used (Fig. 3B). In the case of HTB-35 cell line, cells proliferated to the same extend in medium with $0.5 \%$ BSA alone and in medium supplemented with $10 \%$ FBS.

\section{Co-stimulation of tumor cell migration and intracellular signaling by I-TAC and SDF-1 $\beta$}

The activation of tumor cells migration by I-TAC was tested using chemotaxis assay. HeLa cells were seeded in modified Boyden chamber and subjected to the gradients of I-TAC, SDF-1 $\beta$ and both ligands together. I-TAC alone did not stimulate the migration of tumor cells at concentrations of $1 \mathrm{ng} / \mathrm{ml}$ and $10 \mathrm{ng} / \mathrm{ml}$. The low induction of migration was observed at $100 \mathrm{ng} / \mathrm{ml}$ (Fig. 4A). At the same time cells subjected to SDF-1 $\beta$ gradient showed migration toward concentration of $10 \mathrm{ng} / \mathrm{ml}$ and $100 \mathrm{ng} / \mathrm{ml}$ (Fig. 4A) as observed previ- 


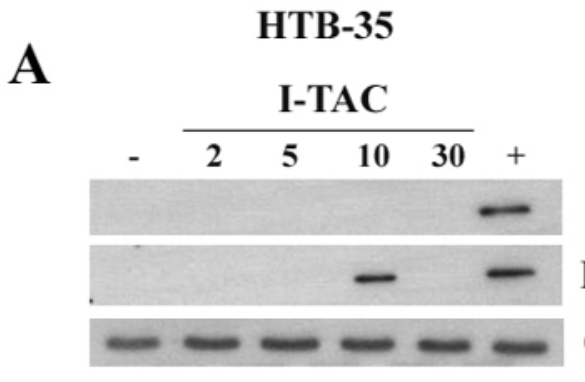

HeLa

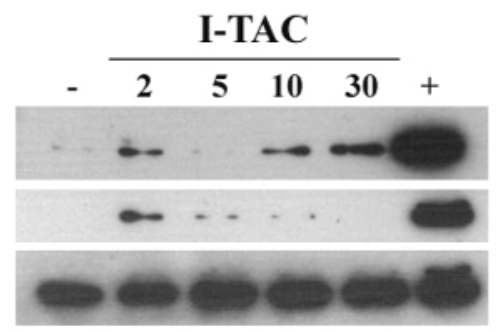

LN 18

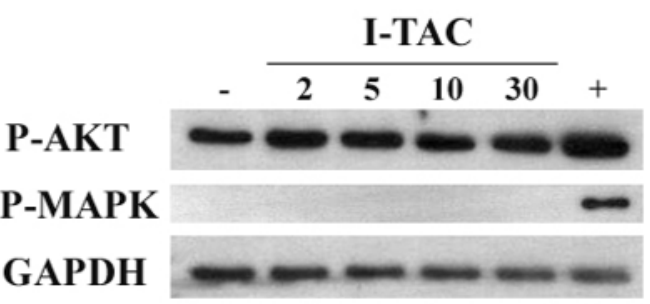

RH 30

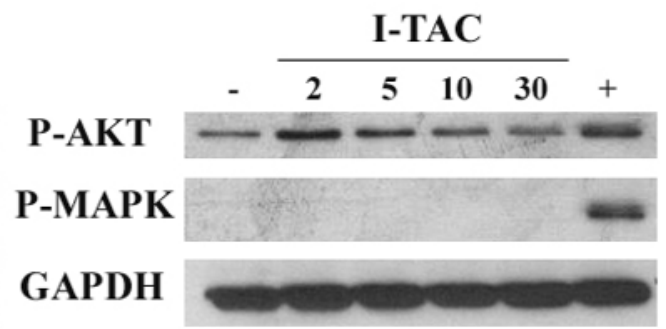

\section{B}

HTB-35

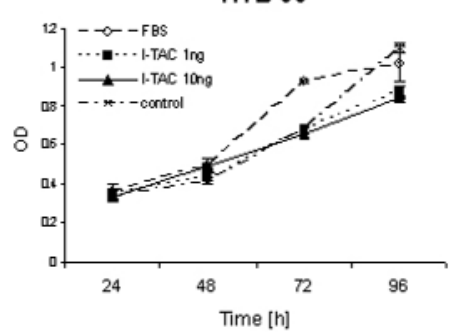

RH30

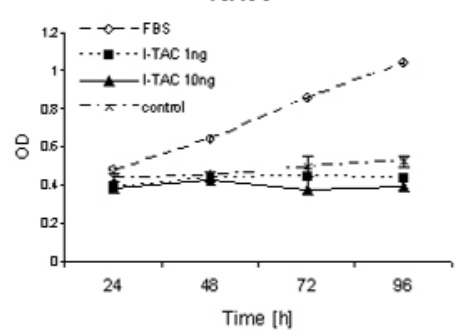

LN229

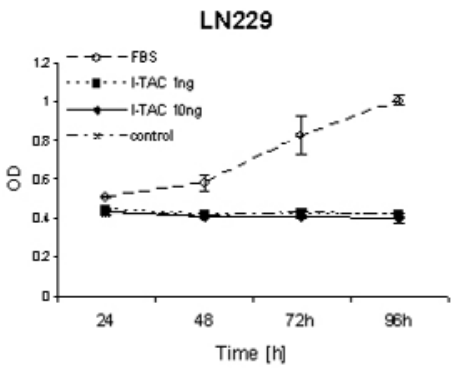

Fig. 3. Analysis of intracellular pathways activation and assessment of tumor cells proliferation after I-TAC stimulation. Panel A - HTB35, HeLa, LN18 and RH30 cell lines were stimulated with I-TAC (100 ng/ml) for 2, 5, 10 and $30 \mathrm{~min}$. The phosphorylation of AKT and MAPK kinases has been assessed. GAPDH detection was used as a control of equal loading of the samples. Experiments were done twice with similar results. Panel B - Tumor cells were grown in medium containing $0.5 \%$ BSA, medium containing $0.5 \%$ BSA supplemented with $1 \mathrm{ng} / \mathrm{ml}$ and $10 \mathrm{ng} / \mathrm{ml}$ of I-TAC. As a positive control medium containing 10\% FBS was used. After 24, 48, 72 and 96 hours the proliferation rate was measured using CellTiter 96 Aqueous One Solution. No changes in tumor cells proliferation were noticed. Experiment was repeated three times with similar results and representative data are shown.

ously [28]. However, we noticed that preincubation of HeLa cells with $10 \mathrm{ng} / \mathrm{ml}$ of I-TAC and subsequent stimulation of migration by low concentration dose of SDF$1 \beta 10 \mathrm{ng} / \mathrm{ml}$ caused stronger migration of tumor cells (Fig. 4A) suggesting that I-TAC might play an important role in sensitizing tumor cells to SDF-1 $\beta$ gradient.

Next, we looked at the co-activation of intracellular signaling by I-TAC and SDF-1 $\beta$. Phosphorylation of MAPK after stimulation with low $(10 \mathrm{ng} / \mathrm{ml})$ and high $(100 \mathrm{ng} / \mathrm{ml})$ concentrations of I-TAC and SDF-1 $\beta$ or their combination were studied. We observed that both concentrations of I-TAC did not induce MAPK phosphorylation after 5 minutes (Fig. 4B) similarly to the data presented in Fig. 3. At the same time SDF-1 $\beta$ stimulated phophorylation of MAPK at both concen- trations (Fig. 4B). However, when I-TAC and SDF-1 $\beta$ where added together at the low concentration (10 $\mathrm{ng} / \mathrm{ml}$ ) the activation of MAPK was significantly higher when compared to the stimulation with each ligand separately and was similar to the stimulation seen after the high concentration of SDF-1 $\beta$ (Fig. 4B).

\section{Discussion}

In this study we investigated the expression of I-TAC binding receptors, CXCR7 and CXCR3, on human cervical carcinoma, glioblastoma and rhabdomyosarcoma cell lines. We showed that CXCR7 is highly expressed on CC, GMB and more aggressive alveolar subtype of RMS. CXCR3 was also expressed on tumor 


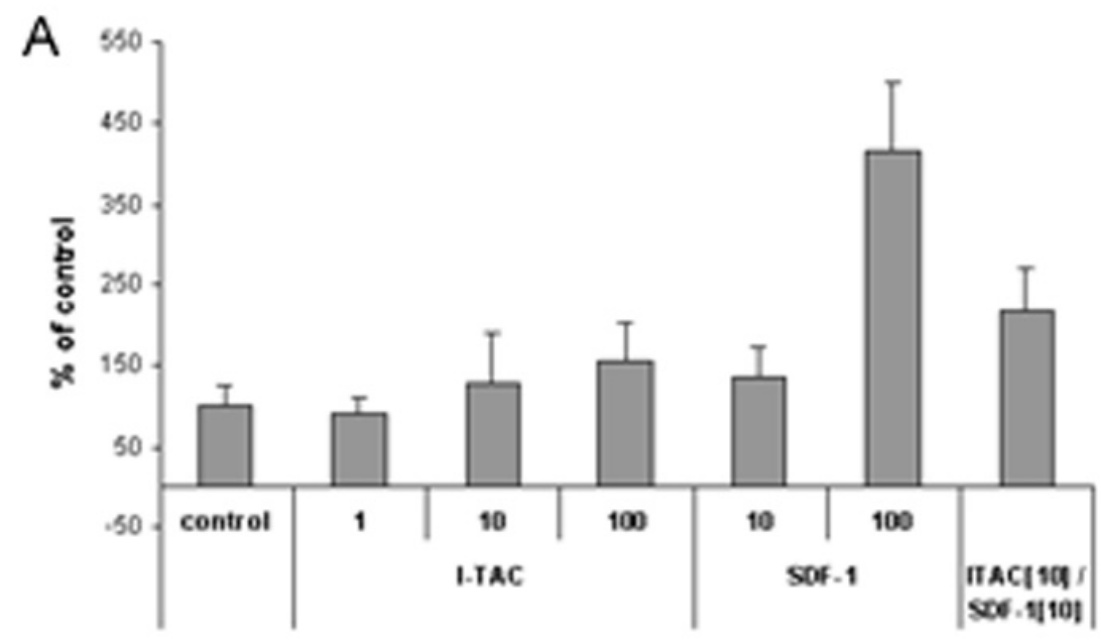

B

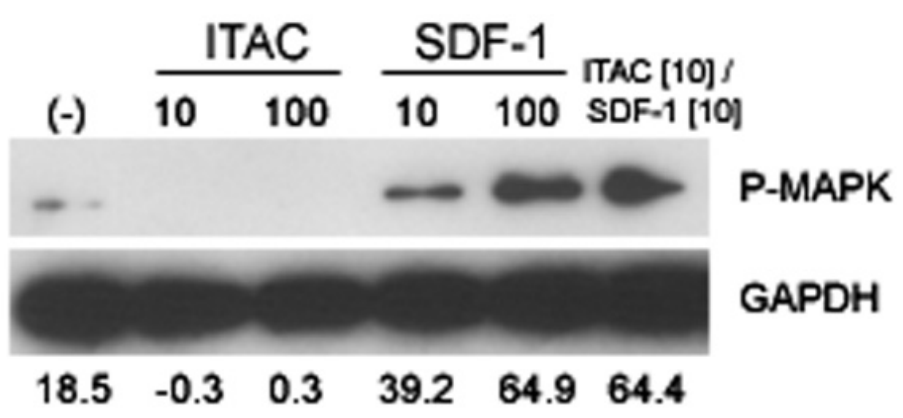

Fig. 4. Stimulation of tumor cell migration and intracellular signaling by ITAC and SDF-1 $\beta$. Panel A - Stimulation of HeLa cells migration by I-TAC and SDF-1 was tested using chemotaxis assay. Ligands were used at low dose (1, $10 \mathrm{ng} / \mathrm{ml})$, high dose $(100 \mathrm{ng} / \mathrm{ml})$ and both at $10 \mathrm{ng} / \mathrm{ml}$. Experiments were repeated twice and average data with SD are shown. Panel B - Activation of MAPK kinase after $10 \mathrm{ng} / \mathrm{ml}$ and $100 \mathrm{ng} / \mathrm{ml}$ of I-TAC and SDF-1 was evaluated. Cells were stimulated for 5 minutes with each ligand alone and with both I-TAC and SDF-1 at low dose. GAPDH was used as the loading control. In order to study the synergistic effect of low doses, a chemokines densitometry analysis was performed. Experiment was done twice and representative blot with densitometry is shown. cell lines but at lower level or was not expressed at all in the case of ARMS. We also showed that I-TAC was able to activate signal transduction pathways responsible for tumor growth and survival. Our data indicate that CXCR7 and, to lower extend, CXCR3 may play a role in various aspects of the biology of human $\mathrm{CC}$, GMB and RMS.

CXCR7 was expressed at the various levels on the surface of different tumor types. The highest expression was seen on alveolar subtype of RMS. All ARMS cell lines expressed CXCR7 at a high level. At the same time ERMS cells expressed this receptor at a very low level. Since ARMS is considered to be more aggressive and metastatic than ERMS [22-24], thus the difference in expression patterns between RMS subtypes could be a result of the more aggressive phenotype of ARMS or it could be also the cause of that phenotype. This distinction needs further analysis. Since ARMS also expresses CXCR4 at higher level than ERMS it is also possible that, according to recent publications, CXCR7 forms heterodimers with CXCR4 and its expression is necessary for CXCR4 signaling regulation [15]. We also studied the expression of CXCR3 in RMS and we found that it is inversely correlated with the expression of CXCR7. More aggressive ARMS subtype expressed CXCR3 only at a very low level or did not expressed CXCR3 at all. At the same time ERMS subtype had much higher expression of this receptor. The meaning of this pattern of expression is unknown and will need further studies using specific inhibitors or RNA interference.

Several chemokine receptors have been shown to play a role in biology of GMB. The expression of CCL3L1, CCR3 and CCR5 was evaluated in tumor tissues and their up-regulation in approximately $60 \%$ of GMB tumor samples was shown in comparison to lower-grade gliomas [29]. CCL3L1 overexpression in GMB cell lines stimulated proliferation of tumor cells [29]. The activation of CXCR2 by IL- 8 has been shown to induce the migration of tumor-associated brain endothelial cells and promote angiogenesis [30]. CXCR1 and CXCR2 has been shown to be expressed in glioma specimens at the various stages including GMB [30]. In the same study the expression of CXCR3 and CXCR4 receptors has also been detected. The expression of CXCR4 was attributed to the invasive behavior of GMB cells [31] and its activation was shown to stimulate the proliferation of GMB cells [32]. In this study we confirmed the expression of CXCR3 by GMB cell lines and for the first time we showed the expression of CXCR7 by GMB cell lines both at mRNA and protein level.

The role of chemokine receptors in biology of CC has not been studied in great details. Recently, our 
group has shown that SDF-1-CXCR4 axis play an important role in stimulating invasive behavior of CC [28]. It was later confirmed by papers showing an important role of SDF-1-CXCR4 axis in lymph node metastasis of this tumor [33-35]. Here, we found that CC cell lines express CXCR7 and CXCR3 receptors. However, the expression of CXCR7 was higher and more uniform. It might suggest an important role of CXCR7 in tumorigenesis of CC particularly in the light of resent observation that CXCR7 and CXCR4 can form heterodimers with stronger affinity to SDF-1. CC cells expressed CXCR3 at low level what might suggest minor role of this receptor in cervical cancer development and progression.

Since chemokines and their receptors has been implicated in the activation of various intracellular pathways and stimulation of cell migration $[4,8,28]$, in this study we have looked at the activation of intracellular pathways (such as PI3K-AKT, RAS-MAPK) and migration after I-TAC stimulation. We found that I-TAC is able to stimulate the phosphorylation of MAPK kinases pathways involved in cell proliferation and protection from apoptosis. However, the activation of growth promoting pathways did not correlate with increased proliferation level. Cells stimulated with I-TAC at two different concentrations did not responded with higher proliferation rate in comparison to control. It might suggest that in tumor cells used in our study signals transmitted through CXCR7 receptor do not activate growth program. This data are in agreement with previous publication showing that stimulation of tumor cells with I-TAC did not affect the proliferation rate in multiple myeloma cells, however in that case the activation signals were transmitted through CXCR3 receptor [36].

Moreover, stimulation of tumor cells with a low dose of SDF-1 $\beta$ and I-TAC resulted in the enhanced activation of MAPK kinase in comparison to the stimulation with SDF-1 $\beta$ or I-TAC alone. Recent data has suggested that binding of I-TAC to CXCR7 receptor can play a role in modulating proliferation and survival [10-12]. CXCR7 was also shown to stimulate migration of cells during embryogenesis of zebra fish [37]. However, the data on tumor cells migration are not clear. In this study we have shown that I-TAC only slightly stimulates migration of tumor cells. However, it can enhance the migration of tumor cells toward SDF- $1 \beta$ gradient.

In summary, our data showed that cervical carcinoma, glioblastoma and rhabdomysarcoma express CXCR3 and CXCR7 receptors on their surface. Moreover, tumor cells stimulated by CXCR3/CXCR7 ligand, I-TAC, activated the intracellular pathways engaged in cell proliferation and protection from apoptosis. I-TAC can also sensitize tumor cells to SDF-1 $\beta$. Thus, I-TAC/CXCR7 and I-TAC/CXCR3 axis might be potential targets for developing antitumor therapy.
Acknowledgments: This study was supported by research grants from the Polish Ministry of Science and Higher Education (N N401 229734 and N N401 010036), grants from Jagiellonian University Medical College (K/ZBW/000143 and K/PBW/ 000455). We would like to thank dr Jacek Kijowski i Mr Marcin Surmiak for technical assistance with densitometric analysis.

\section{Literature}

[ 1] Babico A, Grumolato L, Aaronson SA.. Oncogenes and signal transduction. In: Mendelsohn J, Howley PM, Israel MA, Gray JW, Thompson CB, ed. The molecular basis of cancer. Philadelphia: Saunders Elsevier; 2008, pp. 17-23.

[2] Christopherson K 2nd, Hromas R. Chemokine regulation of normal and pathologic immune responses. Stem Cells. 2001;19:388-96.

[3] Berger EA, Murphy PM, Farber JM. Chemokine receptors as HIV-1 coreceptrs: roles in viral entry, tropism, and disease. Annu Rev Immunol. 1999;17:657-700.

[4] Kucia M, Reca R, Miękus K, Wanzeck J, Wojakowski W, Janowska-Wieczorek A, Ratajczak J, Ratajczak MZ. Trafficking of normal stem cells and metastasis of cancer stem cells involve similar mechanisms: pivotal role of the SDF-1CXCR4 axis. Stem Cells. 2005;23:879-894.

[ 5] Muller A, Homey B, Soto H Ge N, Catron D, Buchanan ME, McClanahan T, Murphy E, Yuan W, Wagner SN, Barrera JL, Mohar A, Verástegui E, Zlotnik A. Involvement of chemokine receptors in breast cancer metastasis. Nature. 2001;410:50-56.

[6] Philips RJ, Burdick MD, Lutz M, Belperio JA, Keane MP, Strieter RM. The stromal derived factor-1/CXCL12-CXC chemokine receptor 4 biological axis in non-small cell lung cancer metastases. Am J Respir Crit Care Med. 2003;167: 1676-1686.

[ 7] Geminder H, Sagi-Assif O, Goldberg L, Meshel T, Rechavi G, Witz IP, Ben-Baruch A. A possible role for CXCR4 and ist ligand, the $\mathrm{CXC}$ chemokine stromal cell-derived factor-1, in the development of bone marrow metastases in neuroblastoma. J Immunol. 2001;67:4747-4757.

[ 8] Libura J, Drukala J, Majka M, Tomescu O, Navenot JM, Kucia M, Marquez L, Peiper SC, Barr FG, Janowska-Wieczorek A, Ratajczak MZ. CXCR4-SDF-1 signaling is active in rhabdomyosarcoma cells and regulates locomotion, chemotaxis and adhesion. Blood. 2002;100:2597-2606.

[ 9] Tavor S, Eisenbach M, Jacob-Hirsch J, Golan T, Petit I, Benzion K, Kay S, Baron S, Amariglio N, Deutsch V, Naparstek E, Rechavi G. The CXCR4 antagonist AMD3100 impairs survival of human AML cells and induces their differentiation. Leukemia. 2008;22:2151-2158.

[10] Balabanian K, Lagane B, Infantino S, Chow KY, Harriague J, Moepps B, Arenzana-Seisdedos F, Thelen M, Bachelerie F. The chemokine SDF-1/CXCL12 binds to and signals through the orphan receptor RDC1 in T lymphocytes. J Biol Chem. 2005;280:35760-35766.

[11] Burns JM, Summers BC, Wang Y, Melikian A, Berahovich R, Miao Z, Penfold ME, Sunshine MJ, Littman DR, Kuo CJ, Wei K, McMaster BE, Wright K, Howard MC, Schall TJ. A novel chemokine receptor for SDF-1 and I-TAC involved in cell survival, cell adhesion, and tumor development. $J$ Exp Med. 2006:203:2201-2213.

[12] Miao Z, Luker KE, Summers BC, Berahovich R, Bhojani MS, Rehemtulla A, Kleer CG, Essner JJ, Nasevicius A, Luker GD, Howard MC, Schall TJ. CXCR7 (RDC1) promotes breast and lung tumor growth in vivo and is expressed on tumor-associated vasculature. Proc Natl Acad Sci U S A. 2007;104:1573515740 .

[13] Raggo C, Ruhl R, McAllister S, Koon H, Dezube BJ, Früh K, Moses AV. Novel cellular genes essential for transformation 
of endothelial cells by Kaposi's sarcoma-associated herpesvirus. Cancer Res. 2005;65:5084-5095.

[14] Sierro F, Biben C, Martínez-Munoz L, Mellado M, Ransohoff RM, Li M, Woehl B, Leung H, Groom J, Batten M, Harvey RP, Martínez-A C, Mackay CR, Mackay F. Disrupted cardiac development but normal hematopoiesis in mice deficient in the second CXCL12/SDF-1 receptor, CXCR7. Proc Natl Acad Sci U S A. 2007;104:14759-14764.

[15] Levoye A, Balabanian K, Baleux F, Bachelerie F, Lagane B. CXCR7 heterodimerizes with CXCR4 and regulates CXCL12-mediated G protein signalling. Blood. 2009;113: 6085-6093.

[16] Panzer U, Steinmetz OM, Paust HJ, Meyer-Schwesinger C, Peters A, Turner JE, Zahner G, Heymann F, Kurts C, Hopfer H, Helmchen U, Haag F, Schneider A, Stahl RA. Chemokine receptor CXCR3 mediates $T$ cell recruitment and tissue injury in nephrotoxic nephritis in mice. J Am Soc Nephrol. 2007;18:2071-2084

[17] Yates C, Whaley D, Y-Chen A, Kulesekaran P, Hebda PA, Wells A. ELR-negative CXC chemokine CXCL11 (IP-9/ITAC) facilitates dermal and epidermal maturation during wound repair. Am J Pathol. 2008;173:643-652.

[18] Sankaranarayanan R, Thara S, Esmy PO, Basu P. Cervical cancer: screening and therapeutic perspectives. Med Princ Pract. 2008; 17:351-364.

[19] Parham DM, Barr FG. Skeletal muscle tumors. In: Fletcher CDM, Unni KK, Mertens F, ed. Pathology and genetics of tumors of soft tissue sarcoma. Lion: IARC press; 2002, pp. 141-154.

[20] Barr FG, Galili N, Holick J, Biegel JA, Rovera G, Emanuel BS. Rearrangement of the PAX3 paired box gene in the paediatric solid tumour alveolar rhabdomyosarcoma. Nat Genet. 1993;3:113-117.

[21] Davis RJ, D'Cruz CM, Lovell MA, Biegel JA, Barr FG. Fusion of PAX7 to FKHR by the variant $\mathrm{t}(1 ; 13)(\mathrm{p} 36 ; \mathrm{q} 14)$ translocation in alveolar rhabdomyosarcoma. Cancer Res. 1994;54:2869-2872.

[22] Barr FG. Molecular genetics and pathogenesis of rhabdomyosarcoma. J Pediatr Hematol Oncol. 1997;19:483-491.

[23] Sorensen PH, Lynch JC, Qualman SJ, Tirabosco R, Lim JF, Maurer HM, Bridge JA, Crist WM, Triche TJ, Barr FG. PAX3-FKHR and PAX7-FKHR gene fusions are prognostic indicators in alveolar rhabdomyosarcoma: a report from the children's oncology group. J Clin Oncol. 2002;20:2672-2679.

[24] Ginsberg JP, Davis RJ, Bennicelli JL, Nauta LE, Barr FG. Upregulation of MET but not neural cell adhesion molecule expression by the PAX3-FKHR fusion protein in alveolar rhabdomyosarcoma. Cancer Res. 1998;58:3542-3546.

[25] van Rij CM, Wilhelm AJ, Sauerwein WA, van Loenen AC. Boron neutron capture therapy for glioblastoma multiforme. Pharm World Sci. 2005;27:92-95.
[26] Brandes AA, Tosoni A, Franceschi E, Reni M, Gatta G, Vecht C. Glioblastoma in adults. Crit Rev Oncol Hematol. 2008:2:139-152.

[27] Lesko E, Gozdzik J, Kijowski J, Jenner B, Wiecha O, Majka M. HSP90 antagonist, geldanamycin, inhibits proliferation, induces apoptosis and blocks migration of rhabdomysoracoma cells in vitro and seeding into bone marrow in vivo. AntiCancer Drugs. 2007;18:1173-1181.

[28] Majka M, Drukala J, Lesko J, Wysoczynski M, Jenson AB, Ratajczak MZ. SDF-1 alone and in co-operation with HGF regulates biology of human cervical carcinoma cells. Folia Histochem Cytobiol. 2006;44:155-164.

[29] Kouno J, Nagai H, Nagahata T, Onda M, Yamaguchi H, Adachi K, Takahashi H, Teramoto A, Emi M. Up-regulation of CC chemokine, CCL3L1, and receptors, CCR3, CCR5 in human glioblastoma that promotes cell growth. J Neurooncol. 2004;70:301-307.

[30] Charalambous C, Pen LB, Su YS, Milan J, Chen TC, Hofman FM. Interleukin- 8 differentially regulates migration of tumorassociated and normal human brain endothelial cells. Cancer Res. 2005;65:10347-10354.

[31] Bajetto A, Barbieri F, Dorcaratto A, Barbero S, Daga A, Porcile C, Ravetti JL, Zona G, Spaziante R, Corte G, Schettini G, Florio T. Expression of CXC chemokine receptors 1-5 and their ligands in human glioma tissues: role of CXCR4 and SDF1 in glioma cell proliferation and migration. Neurochem Int. 2006;49:423-432.

[32] Ehtesham M, Mapara KY, Stevenson CB, Thompson RC. CXCR4 mediates the proliferation of glioblastoma progenitor cells. Cancer Lett. 2009;274:305-312.

[33] Yang YC, Lee ZY, Wu CC, Chen TC, Chang CL, Chen CP. CXCR4 expression is associated with pelvic lymph node metastasis in cervical adenocarcinoma. Int J Gynecol Cancer. 2007; 17:676-686.

[34] Zhang JP, Lu WG, Ye F, Chen HZ, Zhou CY, Xie X. Study on CXCR4/SDF-1alpha axis in lymph node metastasis of cervical squamous cell carcinoma. Int $J$ Gynecol Cancer. 2007; 17:478-483.

[35] Kodama J, Hasengaowa, Kusumoto T, Seki N, Matsuo T, Ojima Y, Nakamura K, Hongo A, Hiramatsu Y. Association of CXCR4 and CCR7 chemokine receptor expression and lymph node metastasis in human cervical cancer. Ann Oncol. 2007; 18:70-76.

[36] Pallegrino A, Antonaci F, Russo F, Merchionne F, Ribatti D, Vacca A, Danmacco F. CXCR3-binding chemokines in multiple myeloma. Cancer Lett. 2004;207:221-227.

[37] Valentin G, Haas P, Gilmour D. The chemokine SDF1a coordinates tissue migration through the spatially restricted activation of Cxcr7 and Cxcr4b. Curr Biol. 2007;17:1026-1031.

Submitted: 29 September, 2009 Accepted after reviews: 11 November, 2009 